\title{
ПСИХОЛОГІЧНІ АСПЕКТИ ФОРМУВАННЯ СОЦІАЛЬНО-ПСИХОЛОГІЧНОГО КЛІМАТУ В СПОРТИВНІЙ ДИТЯЧІЙ ГРУПІ
}

\author{
Вікторія Вінс \\ кандидат психологічних наук, доцент, завідувач кафедри менеджменту, \\ практичної психології та інклюзивної освіти \\ Університет Григорія Сковороди в Переяславі \\ 08401, Україна, м. Переяслав, вул. Сухомлинського, 30 \\ vinsviktoria@gmail.com, https://orcid.org/0000-0002-7285-7711 \\ Світлана Бслякова \\ кандидат психологічних наук, доцент, доцент кафедри менеджменту, \\ практичної психології та інклюзивної освіти \\ Університет Григорія Сковороди в Переяславі \\ 08401, Україна, м. Переяслав, вул. Сухомлинського, 30 \\ svitlanabelacova@gmail.com, https://orcid.org/0000-0003-4995-0253
}

\begin{abstract}
Анотація
Статтю присвячено теоретичному аналізу окремих психологічних аспектів формування психологічного клімату в спортивній дитячій групі. У теоретико-методологічному дослідженні були застосовані наступні методи: теоретичний аналіз, синтез, порівняння, узагальнення, систематизація основних положень психолого-педагогічної науки щодо соціально-психологічного клімату в дитячих спортивних групах для обгрунтування особливостей практичного формування психологічного клімату в дитячій спортивній групі. Визначено, що психологічний клімат у спортивній групі - це відносно стійке налаштування всієї команди, яке пронизує всю систему діяльності й формується на основі суб'єктивного задоволення характером міжособистісних стосунків спортсменів. Індикаторами психологічного клімату в спортивних групах є: ставлення юних спортсменів до навчальнотренувальної та змагальної діяльності; сформованість оптимальних особистісних якостей спортсменів; наявність психологічної сумісності; оптимальність впливів стилю керівництва тренера на клімат в групі тощо. Соціально-психологічний клімат у дитячій групі значно впливає на їх особистість, успішність у спільній діяльності з іншими членами групи (навчання, виховання, спорт, колективні творчі справи), на формування адекватної самооцінки, на створення сприятливої атмосфери міжособистісних взаємовідносин. Встановлено, що у процесі формування сприятливого клімату в дитячій спортивній групі важливою $є$ робота педагогів та психолога, які повинні підтримувати дітей і допомагати у встановленні сприятливого психологічного клімату в їх колективі. При цьому найважливішою умовою формування позитивного або корекції несприятливого психологічного клімату є інтеграція здійснюваних на дитячу групу виховних впливів у єдину систему, що забезпечує безперервність цих процесів. Також для даної діяльності варто використовувати спеціальні форми, до яких відносяться: тематичні тренінгові заняття, орієнтовані на поліпшення групової атмосфери; ділові ігри, спрямовані на вироблення спільного колективного рішення; організація й проведення різних загальногрупових і суспільних заходів тощо.
\end{abstract}


Ключові слова: соціально-психологічний клімат, спортивна група, дитячий колектив, спортивний колектив, спортивна дитяча група.

\section{Вступ}

Наявність сприятливого соціально-психологічного клімату в групі є важливою умовою ефективності іiі функціонування, адже сприятливий клімат забезпечує підвищення продуктивності праці, задоволеність кожного члена групи своєю працею (навчальною чи професійною) та групою зокрема

Проблема соціально-психологічного клімату у будь-якому колективі (від дитячого до виробничого) завжди залишалась актуальною, іiі розгляду присвячені численні наукові дослідження. Так, психологічні засади вивчення клімату в колективі представлено у працях зарубіжних вчених Г. Андрєєвої, В. Бойка, І. Волкова, А. Журавльова, А. Ковальова, Р. Шакурова та ін. Значні напрацювання у напрямку визначення шляхів формування психологічного клімату саме в дитячих колективах містять дослідження Н. Коломінського, Ю. Коломейцева, Р. Шакурова та ін.

Серед доробку українських вчених, присвячених вивченню соціально-психологічного клімату в колективах, вагоме місце займають дослідження Л. Орбан-Лембрик, Л. Карамушки та ін. Розкриття специфіки формування клімату в педагогічному колективі, що включає не лише вчителів, а й всіх учасників освітнього процесу, презентоване у дослідженнях сучасних українських психологів Н. Волкової, Н. Гончарової, Л. Карамушки, М. Молочко, М. Поташника та ін.

Проте, розкриваючи сутність та обговорюючи шляхи формування соціальнопсихологічного клімату в колективах і групах, психологи мало уваги приділяють самим групам. При цьому соціально-психологічний клімат в учнівському середовищі має свою специфіку, формується під впливом цілого ряду психолого-педагогічних факторів, не завжди відрізняється оптимальністю і доброзичливістю до кожного члена групи, колективу.

Особливою дитячою групою, об'єднаною спільною діяльністю та ії ціллю, є дитяча спортивна група, яка прагне до досягнення успіхів у спортивно-ігровій діяльності. Серед соціально-психологічних чинників, що впливають на успішність існування дитячої спортивної групи та досягнення нею високих результатів, науковці С. Бринзак, А. Бузнік, В. Гончаренко, Н. Єршова, К. Кардяліс, І. Оксенюк, О. Пєтухов виділяють психофізіологічну та особистісну сумісність гравців, характер їх міжособистісних відносин, вміле керівництво тренера, позитивний психологічний клімат в групі.

Важливість роботи психолога 3 налагодження сприятливих умов та формування соціально-психологічного клімату в дитячих спортивних групах засвідчується багатьма науковцями, серед яких Г. Бобилєв, В. Горбунова, А. Гринь, В. Гузар, Р. Загайнов, С. Ільїн, Ю. Коломейцев, К. Монахова, С. Одорожа, В. Сопов, О. Федик та ін.

У той же час подальшого пошуку і розробки потребують ефективні форми і методи психологічної роботи, спрямованої на формування позитивного соціально-психологічного клімату в дитячих спортивних групах.

Мета статті полягає у теоретичному аналізі окремих психологічних аспектів формування соціально-психологічного клімату в спортивній дитячій групі. Завдання дослідження: 1) здійснити теоретичний аналіз проблеми розвитку соціально-психологічного клімату у дитячому колективі; 2) охарактеризувати особливості формування соціальнопсихологічного клімату в дитячій спортивній групі. 


\section{Методи дослідження}

У теоретико-методологічному дослідженні застосовувалися наступні методи: теоретичний аналіз, синтез, порівняння, узагальнення, систематизація основних положень психолого-педагогічної науки щодо соціально-психологічного клімату в дитячих спортивних групах для обгрунтування особливостей практичного формування психологічного клімату в дитячій спортивній групі (на прикладі футбольної команди).

\section{Результати та дискусії}

Психологічні аспекти проблеми індивідуальних особливостей взаємодії членів команди цікавлять багатьох вчених та практиків. Спортивна команда - це завжди спортивна група, якій притаманні всі ті соціально-психологічні закономірності, які властиві малим групам (Вінс \& Кангараєва, 2020). Взаємини між членами у спортивній групі поділяються на взаємини між спортсменами і взаємини спортсменів з тренером. У свою чергу, кожен з цих видів взаємин може мати формальний та неформальний характер (Одорожа, 2016: 113).

Формальний характер взаємин у спортивній групі (команді) встановлюється у процесі навчально-тренувальної та змагальної діяльності завдяки виконанням розпоряджень, вказівок i вимог тренера, який регулює процес взаємодії i взаємин членів команди в цій діяльності (Кричевський, 2009; Одорожа, 2016).

Як стверджують С. Одорожа та В. Тютюнник (Одорожа \& Тютюнник, 2016), передбачається, що суворе дотримання правил і інструкцій членами команди гарантує їм задоволення їх особистих потреб, потреб тренера та керівних організацій. Однак, щоб успішно функціонувати, команда повинна передбачати певний «ступінь свободи» в своїй структурі для розвитку зв'язків, що будуються на основі симпатії, взаємному виборі, загальних інтересах та потребах. Ці нерегламентовані, спонтанні взаємини між членами спортивної команди, норми поведінки і дії, що допускають певні відхилення від жорсткого виконання вказівок та інструкцій тренера та керівництва, отримали в психології назву неформальних відносин (Вінс \& Кангараєва, 2020).

Специфіка спортивного колективу відображена і в його організаційній структурі. У багатьох спортивних колективах відповідно до їх особливостей обирається представник команди, який має керувати роботою колективу і представляти його в інших організаціях. Таким чином, лідер обирається і закріплюється не лише дітьми, а й тренером команди. Встановлено, що у кожній спортивній групі є формальний лідер. Однак, як показує практика, він не завжди $є$ авторитетним лідером, який викликає повагу і до якого прислухаються члени групи (Одорожа \& Тютюнник, 2016: 114).

Однак, як стверджує В. Гончаренко, в дитячо-юнацькому періоді занять спортом відбувається закладання основ загальної та спеціальної фізичної підготовки майбутніх спортсменів, а також становлення їх особистості, що в подальшому буде забезпечувати досягнення ними найвищих спортивних результатів (Гончаренко, 2019: 26). Саме тому виникає необхідність психологічної підготовки майбутніх спортсменів, забезпечення для них сприятливих соціально-психологічних умов, що сприяють успішності як у процесі підготовки, так і в процесі спортивно-ігрової діяльності. Вагомим $є$ психологічний супровід юних спортсменів, що включає діагностику соціометричного статусу кожного гравця в команді та визначення індивідуально-психологічних особливостей його особистості: мотивації спортивно-ігрової діяльності, специфіки соціально-психологічної адаптації до умов 
тренувальної i змагальної діяльності, визначення факторів впливу на формування сприятливого психологічного клімату в команді (Вінс \& Кангараєва, 2020).

На думку С. Одорожої, зазвичай в спортивному колективі присутня атмосфера високої взаємної вимогливості і, в той же час, глибокої поваги до особистості кожного члена колективу. У колективі зі стабільним рівнем розвитку особисті інтереси його членів збігаються із загальними інтересами колективу. Переважна більшість членів колективу відчуває почуття гордості за свій колектив, що проявляється у бажанні бути активним учасником його життєдіяльності (Одорожа, 2016).

Переважно усі члени спортивної групи виконують хоча і схожу діяльність, але виконують це по-різному, з огляду на природу ставлення до неї, здібності, особистісні якості, ситуації, закріплену роль в групі тощо. У результаті спільної спортивної діяльності у членів групи формується самооцінка і взаємооцінка вчинків та успішності дій, що дозволяє кожному учаснику порівняти себе з іншими членами, виділити кожному, в тому числі і собі, місце в спортивній команді, визначити статус кожного її члена (Одорожа, 2016: 114).

Визначальними рисами вирізняється і стиль життя та діяльності спортивного колективу. Спортивний колектив характеризується здоровим оптимізмом, що виражається в радісних почуттях і настроях, пов'язаних з участю у спільній діяльності колективу, творчому підйомі, міцну дружбу між членами колективу. У ньому немає місця поганим настроям навіть у винятково важких випадках життя (Вінс \& Кангараєва, 2020).

Таким чином, для гармонійного розвитку спортивної групи у ній має панувати оптимістичний настрій, взаємна вимогливість, дисциплінованість та підтримка, культивуватися повага, що є визначальними ознаками позитивного соціально-психологічного клімату.

У дослідженнях С. Кенані знаходимо визначення, що «психологічний клімат у спортивній групі (команді) - це відносно стійке налаштування (настрій) всієї команди, яке пронизує всю систему діяльності й сформувалося на основі суб'єктивного задоволення характером міжособистісних стосунків спортсменів» (Кенані, 2005: 15).

У той же час клімат регулятивно впливає на частоту цих міжособистісних контактів, щільність і якісну їх сутність. Як зазначають Р. Кричевський, К. Монахова, в цьому проявляється стримуюча функція формальної сторони відносин у спортивній групі по відношенню до розвитку неформальних відносин. Подібні «карантинні» заходи не завжди вдаються, оскільки часом неформальна структура зв'язків майже повністю збігається 3 формальною, або навіть стає провідною. У таких випадках спостерігається «розмивання» формальної структури, що характеризується порушенням субординації в системі «тренер спортсмен», проблемами із дотриманням дисципліни, зниженням критичної оцінки поведінки, особистої відповідальності за свої дії і за спільний результат. Спортивна група перестає відповідати тим завданням, заради розв'язання яких вона була створена, перетворюючись на засіб досягнення цілей вузького кола осіб (Кричевський, 2009; Монахова, 2009).

Згуртованість спортивної команди досягається наявністю спільної мети - перемоги. Спортсмени проводять багато часу разом на тренуваннях, тому система взаємин повинна приносити почуття задоволення від перебування у такому колективі. Досить суттєво впливає на формування оптимальних міжособистісних стосунків у команді діяльність тренера (Вінс \& Кангараєва, 2020).

На думку С. Кенані, до важливих індикаторів психологічного клімату в спортивних командах можна віднести ставлення юних спортсменів до навчально-тренувальної та 
змагальної діяльності; сформованість необхідних особистісних якостей спортсменів; наявність достатньої психологічної сумісності в системах «спортсмен-спортсмен», «тренерспортсмен», оптимальність впливів стилю керівництва тренера на клімат в групі (Кенані, 2005 : 16).

Для успішних спортсменів, як міркує С. Кенані, серед оптимальних особистісних якостей, котрі позитивно впливають на соціально-психологічний клімат в спортивній команді, притаманні наступні: наполегливість, вмотивованість, іні'ціативність, миролюбність, невимушеність. Для «неуспішних» спортсменів, які мають риси особистості, котрі негативно корелюють з позитивним кліматом у групі, характерні: ригідність мислення, розслабленість, відсутність сильних мотивів і бажань, залежність від групи, консерватизм тощо. Крім того, як переконує С. Кенані, на клімат в групі впливає завищена самооцінка окремих іiі членів, зокрема, що супроводжується марнославством, вибагливістю, частими суперечками в групі, неприйняттям інших. I навпаки, при занижених самооцінках юних спортсменів спостерігається зневіра у власні сили, почуття меншовартості, відсутність ініціативності тощо (Кенані, 2005: 16).

Серед факторів, що впливають на формування сприятливого психологічного клімату в спортивній групі, вчені виділяють також сумісність членів команди. Як показують дослідження I. Оксенюк, С. Семенович, сумісність членів спортивної команди зумовлюється наявністю у спортсменів функціональної сумісності, тобто таких психофізіологічних даних, що полегшують колективну ігрову діяльність (Оксенюк \& Семенович, 2017: 71).

Психофізіологічна сумісність гравців спортивної групи, за переконаннями О. Федик, визначається як відповідність гравців за віком, рівнем фізичного та сенсомоторного розвитку, ступенем тренованості і підготовки (Федик, 2013: 127). 3 цього випливає, що психофізіологічна сумісність гравців залежить як від фізичних і фізіологічних особливостей (зріст, сила, витривалість тощо), так і особливостей психічних процесів сприймання, мислення, уваги, пам'яті, емоцій (Вінс \& Кангараєва, 2020).

Досить значущою, як стверджує С. Бринзак, є соціально-психологічна сумісність членів спортивної команди, яка грунтується на загальних цілях, установках та інтересах гравців, поєднанні ціннісних орієнтацій з особистою спрямованістю кожного учасника команди, на переважанні соціального типу поведінки, проявах спрямованості на себе, спілкування чи на групову роботу, особливостях ставлення до товаришів по команді, до наполегливої праці тощо (Бринзак, 2006: 37).

Сумісність між членами команди, окрім зазначеного вище, визначається й характером ïx міжособистісних взаємин. Наприклад, якщо два члени групи виконують певну ігрову дію, але один з них має повільну реакцію, а інший не тільки швидко реагує, а ще й правильно оцінює ігрову ситуацію, очікує швидкої реакції іншого - то в такий момент виникає суперечність, а самі гравці вважаються несумісними. Надалі вони не зможуть досягти успіху парної ігрової діяльності з причини відсутності взаємодії під час виконання сумісних дій (Оксенюк, 2017: 71).

Крім того, суттєвим є характер міжособистісних взаємин гравців у спортивній команді. На переконання О. Федик часто буває так, що слабша команда за техніко-тактичною майстерністю виграє у технічно сильнішої команди. У таких ситуаціях можна дійти висновку, що команда отримала перемогу саме завдяки психологічній згуртованості її учасників (Федик, 2013). За таких умов успішність командної гри залежить не лише від зацікавленості гравців, а й від задоволеності ними умовами перебування у колективі. Згуртованість членів спортивного 
колективу, як стверджує О. Федик, є важливою умовою його майбутніх спортивних успіхів. На формування високої згуртованості спортивної команди впливає не лише врахування тренером ігрових та індивідуально-психологічних особливостей юних спортсменів, але і їх особистісних якостей, які сприяють успішності команди (Федик, 2013: 122).

Досліджуючи особливості формування психологічного клімату в спортивних групах, I. Оксенюк та С. Семенович відзначають велику роль конфліктів та їх вирішення (Оксенюк \& Семенович, 2017).

Важливе значення у вирішенні конфліктів мають не тільки комунікативні навички і вміння членів команди, їх толерантність у ставленні один до одного, а й вміла посередницька робота тренера, який має:

правильно оцінити конфлікту ситуацію; з'ясувати і пояснити гравцям причини іiі виникнення; запропонувати всім учасникам конфлікту висловити свою думку та обгрунтувати іiі; запитати юних спортсменів, які конкретні пропозиції вони можуть запропонувати для вирішення конфлікту; оцінити зусилля всіх учасників колективу щодо вирішення конфлікту; конструктивно і досить критично обгрунтувати свою позицію, чітко окреслити шляхи та умови вирішення конфлікту, а також вимоги, що висуваються до поведінки винуватців конфлікту (Оксенюк \& Семенович, 2017: 72).

Створити хороший соціально-психологічний клімат у спортивному колективі, підібрати команду так, щоб всі її члени не тільки успішно взаємодіяли на полі чи майданчику, а й гармоніювали між собою як особистості, побудувати правильні взаємини в колективі велике мистецтво і велика психолого-педагогічна праця (Одорожа, 2016: 112-113).

Процес формування соціально-психологічного клімату в дитячій спортивній групі, як переконує О. Туліна, вимагає систематичної роботи як тренерів, психологів, так і самих дітей. Подібна робота тісно пов'язана, перш за все, з реалізацією важливих психолого-педагогічних умов, а саме:

- підтримкою позитивного соціально-психологічного клімату в дитячій групі;

- врахуванням психологічних особливостей кожного члена спортивної команди;

- реалізацією конструктивної взаємодії психолога й групи дітей;

- використанням таких форм і методів, що дають змогу долучити дітей до активної позиції в процесі колективної діяльності (Туліна, 2005: 132).

Як міркує О. Палінчак, реалізація цих умов передбачає побудову такої системи роботи 3 колективом, яка може включати різні форми діяльності, зокрема:

- $\quad$ спеціально організовані тренінгові заняття, орієнтовані на оптимізацію групової атмосфери, згуртування, отримання дітьми додаткової інформації один про одного, на установлення міцного зворотного зв'язку, активізацію членів групи;

- $\quad$ ділові ігри, головною метою яких $\epsilon$ формування навичок прийняття спільного рішення, залучення всіх членів команди до дискусії;

- $\quad$ організація й проведення суспільних заходів тощо (Палінчак, 2013).

У дослідженні С. Кенані доведено ефективність проведення тренінг-корекції як основної форми опанування зовнішніх і внутрішніх змін, спрямованих на гармонізацію міжособистісних стосунків юних спортсменів, на зміну своєї поведінки з метою оптимізації психологічного клімату спортивної команди (Вінс \& Кангараєва, 2020). Як стверджує автор, аналіз впливу спеціально організованого психологічного тренінгу на динаміку настроїв гравців футбольної команди засвідчив підвищення настрою у всіх учасників тренінгової роботи, покращення показників психологічного клімату в спортивній групі (Кенані, 2005: 17). 
Таким чином, важливим завданням у процесі формування позитивного психологічного клімату у спортивній групі $є$ розвиток стійкої нормативно-ціннісної основи взаємодій i взаємин. Згуртування дітей на рівні норм і ціннісних орієнтацій відбувається в міру того, як вони все активніше поєднуються між собою в спільній діяльності, що перешкоджає замкнутості спортивної групи й включає тї̈ в ширші зв 'язки й відносини. У цій діяльності група згуртовується й поєднується у різних видах діяльності з іншими спортивними групами - так закладається фундамент її подальшого розвитку (Вінс \& Кангараєва, 2020).

\section{Висновки}

Психологічний клімат дитячого колективу є важливим показником успішності його розвитку, оптимальності поведінково-особистісного становлення дітей, сферою їх підтримки. Соціально-психологічний клімат у дитячій групі значно впливає на їх особистість, успішність у спільній діяльності з іншими членами групи (навчання, виховання, спорт, колективні творчі справи), на формування адекватної самооцінки, на створення сприятливої атмосфери міжособистісних взаємовідносин.

Формування клімату в дитячій спортивній групі залежить від специфіки самої спортивної групи, а також відповідає процесам, які протікають в будь-якій малій групі. До особливостей спортивної групи належить те, що серед членів команди самими дітьми i тренером обирається лідер, представник команди, який зобов'язаний керувати роботою колективу і представляти його в інших організаціях. Також великим є прагнення до одержання спільного результату спортивної діяльності, тому у спортивних групах переважає підтримка i допомога один одному, однак високим є дух високої взаємної вимогливості, і в той же час глибокої поваги до особистості кожного члена колективу.

Важливою умовою формування позитивного психологічного клімату у спортивному колективі є інтеграція здійснюваних на дитячу групу виховних впливів у єдину систему, що забезпечує безперервність цих процесів. 3 цією метою можна використовувати спеціальні психологічні заходи, зокрема: тематичні тренінгові заняття, орієнтовані на поліпшення групової атмосфери; ділові ігри, спрямовані на вироблення спільного колективного рішення; організація й проведення різних загальногрупових заходів тощо.

Перспективним напрямком подальших досліджень означеної проблеми вбачаємо виокремлення вікових та гендерних особливостей учасників дитячої спортивної групи як чинників формування соціально-психологічного клімату у ній.

\section{Література}

1. Бринзак, С. (2006). Психологічна сумісність та ії оцінка в спортивній команді. Молода спортивна наука України : зб. наук. пращьь з галузі фіз. культури та спорту, 10(4), 36-40.

2. Вінс, В., \& Кангараєва, К. (2020). Особливості формування сприятливого психологічного клімату в спортивній дитячій групі в контексті впровадження інклюзивної освіти. Міжнародна наукова інтернет-конференція «Практична психологія в інклюзивному середовищі», (с. 207-212). Переяслав : Видавець Я.М. Домбровська.

3. Гончаренко, В. (2019). Дослідження соціально-психологічного клімату футболістів на етапі попередньої базової підготовки. Слобожанський науково-спортивний вісник: Матеріали ХІХ Міжнародної науково-практичної конференції «Фізична культура, спорт $i$ здоров'я: стан, проблеми та перспективи», 6K, 26-28.

4. Кенані, С.Б. (2005). Індикатори психологічного клімату спортивної команди (Автореф. дис. канд. наук з фіз. виховання і спорту). Київ.

5. Кричевский, Р.Л. (2009). Социальная психология малой группыл. Москва : Аспект Пресс. 
6. Монахова, К.В. (2009). Влияние индивидуально-коррекционной работы на взаимоотношения в спортивной команде. Мир образования - образование в мире, 2, 253259.

7. Одорожа, С.М. (2016). Соціально-психологічні особливості відносин спортивної групи. Наукова конференція «Соціально-психологічний та філософський підхід до проблем сучасного суспільства», (м. Сєвєродонещьк, 8 лютого - 1 березня 2016 р.), (с. 112-113). Сєвєродонецьк : СНУ ім. В. Даля,

8. Оксенюк, I. (2017). Значення факторів психологічної сумісності у взаємовідносинах між тренером та гравцями футбольної команди. Нова педагогічна думка, 3(91), 71-73.

9. Палінічак, О.І. (н.д.). Шляхи формування оптимального психологічного клімату в педагогічному колективі. Режим доступу: http://www.library.kherson.ua/klas/18/pedagog skarbnychka/metod_porady/palinichak.doc.

10. Тулина, О.О. (2005). К вопросу о формировании коллектива учащихся. Сборник научных трудов Северо-Кавказского государственного технического университета. Серия «Гуманитарные науки», 2(14),129-135.

11. Федик, О.В. (2013). Психологія спорту : матеріали для самопідготовки до семінарських занять для студентів спеціальності «Психологія». Івано-Франківськ : Інін.

\section{References}

1. Brynzak, S. (2006). Psykholohichna sumisnist ta yii otsinka v sportyvnii komandi. Moloda sportyvna nauka Ukrainy : zb. nauk. prats z haluzi fiz. kultury ta sportu. Vyp. 10. T. 4. 36-40. [in Ukrainian].

2. Vins, V. \& Kanharaieva, K. (2020). Osoblyvosti formuvannia spryiatlyvoho psykholohichnoho klimatu v sportyvnii dytiachii hrupi v konteksti vprovadzhennia inkliuzyvnoi osvity. Praktychna psykholohiia v inkliuzyvnomu seredovyshchi: Zbirnyk naukovykh statei Mizhnarodnoi naukovoi internet-konferentsii. Pereiaslav: Vydavets Ya. M. Dombrovska. 207-212. [in Ukrainian].

3. Honcharenko, V. (2019). Doslidzhennia sotsialno-psykholohichnoho klimatu futbolistiv na etapi poperednoi bazovoi pidhotovky. Slobozhanskyi naukovo-sportyvnyi visnyk: Materialy XIX Mizhnarodnoi naukovo-praktychnoi konferentsii «Fizychna kultura, sport i zdorovia: stan, problemy ta perspektyvy». 6K. 26-28. [in Ukrainian]

4. Kenani, S. B. (2005). Indykatory psykholohichnoho klimatu sportyvnoi komandy (Avtoref. dys. kand. nauk z fiz. vykhovannia i sportu). Kyiv. [in Ukrainian]

5. Krichevskij, R. L. (2009). Socialnaja psihologija maloj gruppy. Moskva: Aspekt Press. [in Ukrainian].

6. Monahova, K. V. (2009). Vlijanie individualno-korrekcionnoj raboty na vzaimootnoshenija v sportivnoj komande. Mir obrazovanija-obrazovanie v mire. 2. 253-259. [in Russian].

7. Odorozha, S. M. (2016). Sotsialno-psykholohichni osoblyvosti vidnosyn sportyvnoi hrupy. Sotsialno-psykholohichnyi ta filosofskyi pidkhid do problem suchasnoho suspilstva : materialy nauk. konf, Sievierodonetsk : SNU im. V. Dalia, 112-113. [in Ukrainian].

8. Okseniuk, I. (2017). Znachennia faktoriv psykholohichnoi sumisnosti u vzaiemovidnosynakh mizh trenerom ta hravtsiamy futbolnoi komandy. Nova pedahohichna dumka. 3 (91). 71-73. [in Ukrainian].

9. Palinichak, O. I. Shliakhy formuvannia optymalnoho psykholohichnoho klimatu v pedahohichnomu kolektyvi [Elektronnyi resurs]. Rezhym dostupu: http://www.library.kherson.ua/klas/18/pedagog_skarbnychka/metod_porady/palinichak.doc. [in Ukrainian].

10. Tulyna, O. O. (2005). K voprosu o formyrovanyy kollektyva uchashchykhsia. Sbornyk nauchnblkh trudov Severo-Kavkazskoho hosudarstvennoho tekhnycheskoho unyversyteta. Seryia «Humanytarnble nauky». 2 (14). 129-135. [in Russian].

11. Fedyk, O. V. (2013). Psykholohiia sportu : materialy dlia samopidhotovky do seminarskykh zaniat dlia studentiv spetsialnosti «Psykholohiia». Ivano-Frankivsk : Inin. [in Ukrainian]. 


\title{
PSYCHOLOGICAL ASPECTS OF SOCIO-PSYCHOLOGICAL CLIMATE FORMATION IN CHILDREN SPORTS GROUP \\ Viktoria Vins
}

\author{
PhD in Psychology, Associate Professor, Associate Professor of the \\ Department of Management, Practical Psychology and Inclusive Education \\ Hryhorii Skovoroda University in Pereiaslav \\ 30, Sukhomlynsky Street, Pereiaslav, Ukraine, 08401 \\ vinsviktoria@gmail.com, https://orcid.org/0000-0002-7285-7711 \\ Svitlana Beliyakova \\ PhD in Psychology, Associate Professor, Associate Professor of the \\ Department of Management, Practical Psychology and Inclusive Education \\ Hryhorii Skovoroda University in Pereiaslav \\ 30, Sukhomlynsky Street, Pereiaslav, Ukraine, 08401 \\ svitlanabelacova@gmail.com, https://orcid.org/0000-0003-4995-0253
}

\begin{abstract}
This article is dedicated to theoretical analysis of separate psychological aspects of sociopsychological climate formation in a children sports group. The following methods are used in theoretical and methodological research: theoretical analysis, synthesis, comparison, generalization, systematization of the main provisions of psychological and pedagogical science about sociopsychological climate in children sports groups to substantiate the peculiarities of practical psychological climate formation in children sports group. The psychological climate in a sports group is determined to be a relatively stable setting of the whole team, which permeates the entire system of activities and is formed on the basis of subjective satisfaction with the nature of interpersonal relationships of athletes. Indicators of the psychological climate in sports groups are: attitude of young athletes to training and competitive activities; formation of optimal personal qualities of athletes; presence of psychological compatibility; optimal coach's leadership style influences on the climate in the group, etc. Socio-psychological climate in the children group significantly affects their personality, success in joint activities with other members of the group (education, upbringing, sports, collective creative work), the formation of adequate self-esteem, the creation of a favorable atmosphere of interpersonal relationships. It is established that in the process of forming a favorable climate in a children sports group, the work of teachers and psychologists is important, who should support children and help establish a favorable psychological climate in their team. At the same time, the most important condition for the formation of a favorable or correction of an unfavorable psychological climate is the integration of educational influences on the children group into a single system that ensures the continuity of these processes. Also for this activity it is necessary to use special forms which include: thematic training sessions aimed to improve the group atmosphere; business games aimed to develop a joint collective decision; organization and holding of various general group and public events, etc.
\end{abstract}

Keywords: social and psychological climate, sports group, children collective, sports collective, sports children group. 